\title{
STATE INTERVENTION ON THE MARKET FOR NATURAL DAMAGE INSURANCE IN EUROPE
}

\author{
THOMAS VON UNGERN-STERNBERG
}

\author{
CESIFO WORKING PAPER NO. 1067 \\ CATEGORY 9: INDUSTRIAL ORGANISATION
}

OCTOBER 2003

Presented at Venice Summer Institute, Workshop on Insurance, July 2003

\footnotetext{
An electronic version of the paper may be downloaded

- from the SSRN website:

www.SSRN.com

- from the CESifo website:

www.CESifo.de
} 


\title{
STATE INTERVENTION ON THE MARKET FOR NATURAL DAMAGE INSURANCE IN EUROPE
}

\begin{abstract}
In this paper we briefly summarise the results of our studies of the property insurance market in 5 countries, Britain, Spain, France, Switzerland and Germany. We then draw conclusions, how the market for insurance against natural disasters (such as floods or subsidence) should be institutionally organised. Both for reasons of efficiency (lower administrative and sales costs) and to reduce the scope of risk selection, public monopolies should play an important role on this market. A further major advantage of the monopoly solution is the fact, that public insurers have a strong incentive to actively participate in prevention.
\end{abstract}

JEL Classification: D21, L84, G22.

Thomas von Ungern-Sternberg

DEEP, Ecole des HEC

1015 Lausanne

Switzerland

Thomas.VonUngern-Sternberg@hec.unil.ch 


\section{Introduction}

Over the last decades a number of European countries have witnessed a substantial increase in costs due to "natural disasters", in particular flooding and subsidence. More and more observers seem to agree that this increase is due at least in part to climatic changes caused by the greenhouse effect. Since the trend of increased $\mathrm{CO}_{2}$ emissions is by no means broken, it seems reasonable to anticipate further increases in the cost of claims due to climatic factors.

In the short and medium run, this raises two questions: First, how can preventive measures be organised so as to minimise the economic costs of floods, subsidence, storms, avalanches and other natural causes. Second, how can one organise the market for insurance against natural damage in such a way that the population obtains insurance cover at the lowest possible cost. We shall see that the two problems are not unrelated.

In a recent book we have studied the property insurance market in 5 different European countries, Britain, Spain, France, Switzerland and Germany ${ }^{1}$. The market organisation in these countries differs substantially. Our comparisons thus allow us to obtain some interesting empirical insights about the impact of different types of government intervention. In the first five sections of this paper we shall summarise the main results from each of the country studies. We shall then briefly review what we consider to be the main driving forces underlying our observations. Finally we shall draw some lessons for the types of intervention that would make sense for those countries, where there is currently little state intervention and the social cost of market failure is important.

Our main conclusions can be summarised as follows:

\footnotetext{
${ }^{1}$ Thomas von Ungern-Sternberg (2003) "Property Insurance in Europe: the Limits of Competition" Oxford University Press
} 
- In the absence of state intervention the more exposed customers typically do not have proper insurance cover against natural damage. Problems of risk selection play an important role in this market.

- Both cross section and time series evidence show that in the presence of state monopoly premiums are substantially lower than under competition. One of the driving forces behind this observation are the monopolies' considerable savings in terms of sales and administrative costs.

- Compulsory state monopolies do not have to cope with problems of adverse selection. They can work with premium rates that do not adequately reflect true risk. This leads to a certain amount of redistribution between good and bad risks but it also results in significant savings in screening costs.

- There is a natural complementarity between prevention and insurance. Preventive measures to reduce the incidence of natural disasters typically take the form of local public goods. Examples include regional planning, special building norms for exposed areas, the construction of dams, well trained and equipped fire fighting organisations etc. State (local) monopolies have a strong incentive to develop and subsidise these activities, as they obtain a direct return on the resources they spend on prevention: the costs of claims fall.

Our international comparisons suggest that countries which consider introducing or modifying a system of natural damage insurance should keep to the following framework.

Insurance should be compulsory, and a large fraction of total insurance premiums should flow to a national (or regional) state monopoly. To keep administrative costs low the premium should be collected by the direct insurers company and then passed on to the state monopoly. The example of Spain shows that such a system can be implemented to the satisfaction of both the customers and the direct insurers.

Premium income should be used not just to reimburse claims, but also to participate in various kinds of damage prevention activities. In particular, the state monopolies should be given the right to directly intervene in the process of land zoning. This is an efficient way to internalise 
the externalities of better prevention. The Swiss example shows that integrating prevention and insurance leads to a substantial increase in the resources devoted to preventive measures and to lower claims' costs.

Claims settlement can be done either directly by the state monopoly (as in Spain) or indirectly through the private insurance (as in France). In the latter case incentives must be created to limit moral hazard problems by the insurance agent (excessive reimbursement).

Let us now turn to our country studies.

\section{Britain}

We shall start our country studies with Britain, because British policy makers traditionally intervene only to a very limited extent in the insurance industry. Britain offers a textbook example of a free insurance market. We note the following features of property insurance in Britain:

Approximately $35 \%$ of premium income is regularly used to cover commissions, administrative and operating costs. Only about $50 \%$ of premium income is paid out to customers to cover claims. Competition by sales representatives appears to play a much greater role in this market than price competition.

While private insurers offer all customers comprehensive insurance against fire, such cover is not universally available against natural damage. Since the middle of the 1970's Britain has suffered a substantial (£3.5 billion) unexpected increase in subsidence related damage. Subsidence is a particularly interesting form of natural damage for our purposes since the claims are concentrated in regions with particular types of soil (clay). Britain thus offers a textbook study how a competitive insurance system reacts, when there is an unexpected increase in damage that is (very) unevenly distributed among the population. The results are striking. House owners in the affected regions had to accept both substantial increases in premium rates (premiums increased by a factor of 5) and important rises in their excesses (up to $£ 3^{\prime} 000$ ). Insurance companies started spending large sums to try to identify the bad risks. And as the premium differentials increased, customers in their turn had strong incentives to try to prove to the insurance companies that they belonged to better risk categories. 
The British case study illustrates in an exemplary fashion how an initial equilibrium with a homogenous premium structure can change completely as a result of new information about the distribution of potential damage. Premiums (and excesses) become more differentiated, and substantial resources are invested both by the customers and the insurance companies into ever finer risk classifications. House owners with buildings that were for many years considered good risks, had to cope with substantial increases in the cost of insurance. The ability of insurance companies to adjust insurance conditions rapidly as new information becomes available means that the customers have to bear a substantial cost of risk themselves. Insurance cover is in a very real sense incomplete.

\section{Spain}

Spain has a compulsory state monopoly for disaster insurance, the Consorcio de Compensacion de Seguros (the "Consorcio" for short). It is a good illustration of the benefits that a state property insurance monopoly can provide customers.

The Consorcio covers its administrative and commission costs with a mere $10 \%$ of its premium income. $5 \%$ are paid to private insurers for premium collection, $5 \%$ are required to cover the Consorcio's administrative costs, including claims processing. Spanish private insurers, on the other hand, spend almost $40 \%$ of their premium income on administrative and commission costs. The Consorcio implies substantial cost savings for its customers.

The Consorcio offers extensive cover against damage from “disasters”, such as floods, storms, earthquakes and terrorist attacks. Because insurance is compulsory, the Consorcio can operate with a system of flat-rate premiums. It does not have to fear losing the better risks to a competitor. Neither the Consorcio nor the customers spend money trying to solve problems of risk selection. The Consorcio illustrates two of the main advantages of having a state monopoly on the property insurance market. Considerably lower costs and premiums coupled with universal coverage (at a low premium rate).

In principle the Consorcio's monopoly is in direct conflict with the $3^{\text {rd }}$ EU Non-Life Insurance Directive, which intended to open all EU markets for property insurance to (international) competition. However, since the Spanish refused to abandon the Consorcio, the EU had to 
reach a compromise. It decided to treat the payments made to the Consorcio not as "insurance premiums" but as a "surcharge”. All house owners are obliged to pay this "surcharge” and are then automatically insured against disasters. However, there is nothing to prevent owners from buying the same or similar insurance from private insurers. Should they decide to do so, they lose their cover with the Consorcio, even though the surcharge will still have to be paid. According to the EU's interpretation, the Consorcio is not a monopoly, as the customers have the option to buy insurance in the free market. This solution is perfectly acceptable to the Spanish monopoly. No customer in his right mind will make use of this option, since he has already paid for the insurance cover with the Consorcio. Taking out insurance with a private insurer would amount to "throwing away” the cover already paid for.

Since the Consorcio provides insurance against disasters, it needs considerable reserves to cover itself against a major event. A state monopoly like the Consorcio has no shareholders who have a claim on dividends. All the interest income the Consorcio earns on its reserves thus flows into its reserve fund. As a result the reserve fund increases considerably faster than the difference between premium income and claims payments. The interest income is sufficient to cover the Consorcio’s entire administrative costs, while still making a substantial contribution to the stock of reserves. This is illustrated in figure 1. The point deserves particular emphasis because all too often the public discussion focuses only on the Claims/Premium ratio, and neglects the usually substantial interest income insurance companies earn on their reserves. 
Figure 1

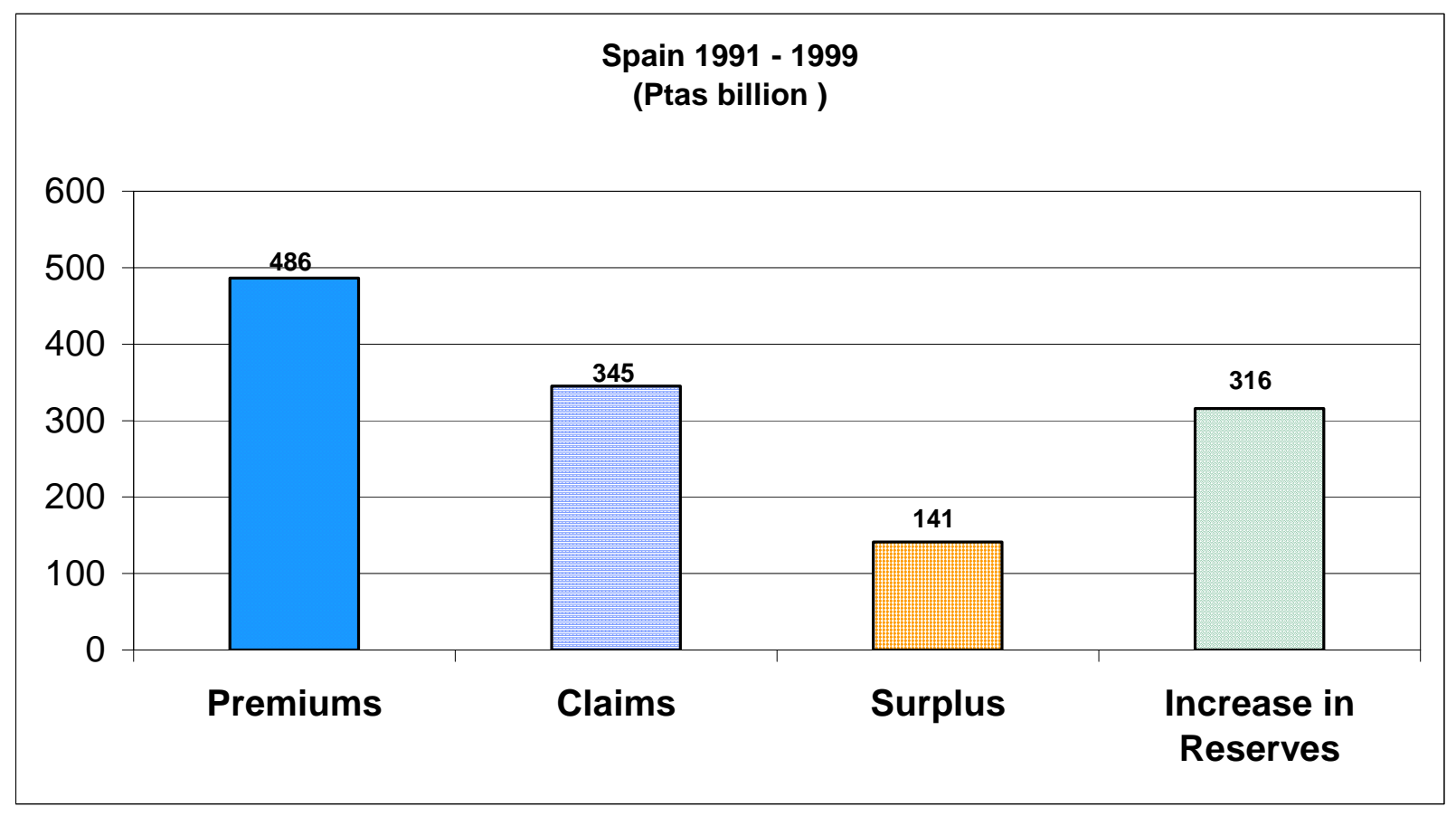

\section{France}

French politicians have long been aware that the problem of risk selection can lead to serious problems in a non-regulated market for disaster insurance. Bad risks either do not find cover, or only at unaffordable prices. Unfortunately, the French government was not prepared to follow the example of its Spanish neighbour and create a state monopoly insurance. Instead, in the beginning of the 1980's it introduced a mixed system in which private insurers are legally obliged to offer disaster insurance at a flat-rate premium fixed by the government. They then have the possibility of reinsuring these risks with a state institution, the Caisse Centrale de Réassurance (CCR). At first glance, this might appear to be an attractive solution; on closer inspection it has several serious drawbacks.

First, the private insurers negotiated a "handling fee" of almost 25\% with the CCR to cover their "costs” of collecting the premiums. These “costs” are of course purely fictitious. Disaster 
insurance is compulsory and automatically added on to all property insurance contracts, particularly fire insurance. (This is also the reason why Consorcio in Spain pays insurers only $5 \%$ for the collection of premiums.) The CCR clearly suffers from "regulatory capture".

Furthermore, while private insurers have the possibility of reinsuring with the CCR, they are not obliged to do so. As was to be expected, the large French insurers quickly realized that collecting premiums from the good risks and taking out only little reinsurance cover with the CCR was a lucrative business. The bad risks then had a tendency to land in the hands of the smaller local insurers, who made full use of the reinsurance cover offered by the CCR. The consequences of these two problems were disastrous for the CCR.

In 1995, the share of total premium income that was passed on to the the CCR was $45 \%$. In the same year, the CCR had to pay $\mathbf{9 8 \%}$ of the claims caused by the three hurricanes in the DOM (Martinique and Guadeloupe). With a premium volume of FF 24 mn (from the DOM), the CCR had to pay claims in the order of FF $650 \mathrm{mn}$.

Over the period 1982-1999 the system as a whole generated a surplus of approximately 33 billion francs ${ }^{2}$. Nevertheless the CCR, was on the verge of bankruptcy in 1999, and the government had to inject a further 1 billion francs. The CCR reduced the maximal cover it would provide in terms of proportional reinsurance to $60 \%$. At the same time premiums and excesses for the customers were raised by 30\%. As a result of this increase the Claims/Premium rate has now fallen to only $45 \%$. Disaster insurance is a lucrative source of profits for French private insurers. Should there be a large-scale natural disaster, it will not be the insurers but the taxpayers who will have to foot the bill. The CCR offers private insurers low cost unlimited stop-loss cover.

The French example well illustrates the difficulties or impossibility of designing an efficient mixed system. It also highlights the importance of effective prevention. In most countries the lion's share of natural disaster damage is due to floods. The best way to prevent this type of damage is to ensure that there is no construction in highly exposed areas. French legislation provides for municipalities to draw up zoning plans and that particularly endangered areas are entirely dezoned. It is easy to understand why progress in this area has been exceedingly slow.

\footnotetext{
${ }^{2}$ For the calculations cf. von Ungern-Sternberg (2003)
} 
The benefits from dezoning accrue mainly to the insurers in the form of lower claims payments, the costs are born by the municipalities and the local residents, whose land loses value as a result of dezoning.

\section{Switzerland}

Switzerland has a dual system in property insurance. In 19 of its 26 cantons, owners are legally obliged to purchase cover against both fire and natural damage from a cantonal insurance monopoly (CIM). The inhabitants of the remaining 7 cantons can obtain property insurance only from private providers. This structure allows cross-sectional comparison of the two systems (market vs. public monopoly). A summary comparison between the two systems is shown in Figure 2. There is a number of striking differences between the two systems.

\section{Figure 2}

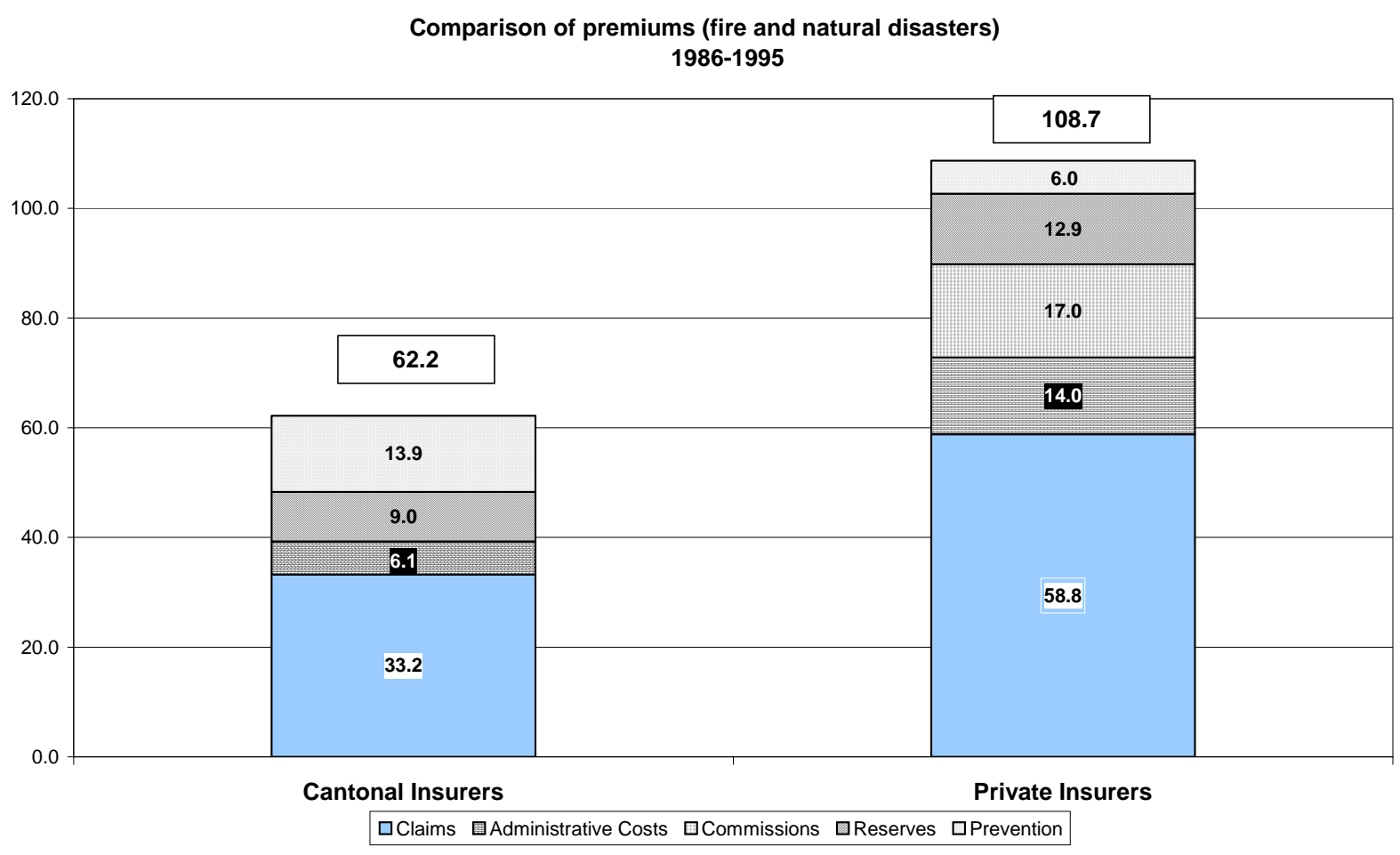


Over the period 1986-1995 the average premium rate charged by the CIM was roughly half of that of the private insurers. A large part of this difference was due to their lower administrative costs and commissions. The CIM premium rate was $0.62 \%$ of sum insured, they spent only $0.06 \%$ of sum insured on administrative costs and, being state monopolies, they had no commission costs. The premium rate of the private insurers was $1.09 \%$ of sum insured; they spent fives times as much, over $0.30 \%$ of sum insured, on commissions and administrative costs. The state monopoly allowed the customers significant savings.

The CIM are not just insurance companies; they are also heavily involved in prevention. There are good reasons to combine these two tasks. The institution that stands to gain most from better prevention is also in charge of organising and financing preventive efforts. The presence of this incentive structure has had significant effects. The CIM invest more than twice as much $(0.15 \%$ o of sum insured) in prevention than the private insurers $(0.06 \%$ o of sum insured) and their claims levels are significantly lower. It is unfortunately very difficult to establish with certainty to what extent this lower incidence of damage is due to better prevention, to better exogenous conditions or to differences in claims settlement.

Although the CIM have always offered lower premium rates, they have managed to build up substantial reserves, on which they of course earn interest. Since they have no shareholders, to whom they have to pay dividends, they keep the interest income. Their capital income is equivalent to approximately $40 \%$ of their premium incomes. This has allowed them to decrease their premium rate by a further $20 \%$ in recent years. They currently operate with premium rates that are insufficient to cover their costs. However, their capital income permits them to cover their deficits and further increase their reserve funds.

The CIM with their strong involvement in prevention, are clearly a very efficient organisations. Customers enjoy low-price comprehensive cover against fire and natural damage. At the same time, there is substantial investment in prevention and the incidence of damage is comparatively low. 


\section{Germany}

Before the $3^{\text {rd }}$ EU Non-Life Insurance Directive came into force in 1994, many German Länder had compulsory monopoly institutions (CMI) for property insurance. Most of them covered only fire and storm, except for the property insurance company of BadenWürttemberg (GVBW) which, just like the Swiss CIM, offered comprehensive cover against natural damages, including floods. The German experience of the 1990s provides time series comparisons of what happens when former monopolies are opened to competition.

The first point to note is that the former monopolies substantially increased their expenditures on sales representatives and administrative costs to survive in the free market. Within a mere 6 years these costs more than tripled in all the Länder studied. The share of these costs in premium income increased from roughly $10 \%$ to over $20 \%$.

The cost increases had a strong impact on premium rates, in particular those charged to small customers. The increase in premium rates was between $40 \%$ and $80 \%$ depending on the Land. In spite of this, five years after market liberalisation, approximately 95\% of customers were still loyal to the former monopolies. One of the reasons for this is that their premium rates are still relatively low.

The former CMI's contributions to prevention dropped by around 50\%. Prevention is now largely financed through general taxation.

The GVBW had originally hoped to maintain its comprehensive insurance cover against natural damage even in a liberalised market. After three years of above-average flood claims, it had to abandon this plan; otherwise, it would have run the danger of losing its good risks to its competitors. In 1996, it started sending letters to its flood victims informing them of the termination of their insurance contract. At the same time it offered these customers new contracts, in which they would have to accept an excess of DM 5,000. The GVBW ran no risk of losing these customers to the competition; no private insurer would accept these evidently bad risks. Free competition and comprehensive insurance cover against natural damage clearly do not go together well. 
Let us now turn to some theoretical considerations that might help explain the empirical observations sketched out in the preceeding sections.

\section{Intransparent markets}

The first obvious point of interest is the substantial difference in commissions and administrative costs between private insurers and state monopolies. To understand this difference one presumably has to focus on problems of incomplete information.

Property insurance is a highly standardised product, both for the state monopolies and in the more competitive environments. There are several reasons why the scope of product differentiation is very limited even for private insurers.

- When insurance is compulsory, the legal constraints severely limit the potential for product differentiation.

- Most properties serve to guarantee a mortgage loan. The financial institutions have strong incentives to see to it that the property is covered by a reasonably complete guarantee against total or partial destruction.

- Most house owners face financial ruin if their property were to be destroyed without compensation. They thus want full cover against this risk.

A good indication that the consumers' demands are indeed quite homogeneous is the fact that the former German state monopolies saw no need to introduce any additional differentiation to their offer when their market was opened to competition. They kept selling the same standardised product, but they did so with much greater sales and marketing efforts.

In spite of this homogeneity, we observe in all the countries we have studied that private insurance companies spend substantial amounts on sales efforts. The sales representatives typically get between $15 \%$ and $20 \%$ of annual premium income, and in-house administrative and advertising costs add up to an equivalent amount. Claims settlements typically make up only about $50 \%$ of premium income. If one tries to think about the property insurance market in terms of a standard model of monopolistic competition the standard Lerner condition ( $\mathrm{p}_{\mathrm{i}}{ }^{-}$ $\left.\mathrm{C}_{\mathrm{i}}\right) / \mathrm{p}_{\mathrm{i}}=1 / \mathrm{E}_{\mathrm{i}}$ (the price-cost margin is inversely proportional to the own-price elasticity of 
demand) would seem to indicate that the elasticities of substitution between the offers of different insurance companies are only quite low.

The main explanation for this apparent contradiction between the low elasticities of substitution and the above mentioned homogeneity of insurance contracts is probably the lack of transparency on this market. Property insurance is a classic example of a "credence good". The property owner usually has definite proof about the quality of his insurance cover only once damage has occurred. The exact legal conditions of insurance are not transparent for the layman. And it is well known that insurance companies will sometimes, in the case of smaller claims, reimburse their customers even if their legal obligation to do so is not entirely clear. When they refuse to pay, the process of taking them to court can be quite costly and take years.

This lack of transparency has two consequences. First, customers may be inclined to "judge quality by price", i.e. prefer to buy a slightly more expensive cover in the hope that for the higher price they also obtain better treatment. Second, customers may prefer to be insured by a company, which allows them to have contact with a person they consider to be trustworthy, the insurance agent. The prevalence of insurance agents and the lack of success by low cost direct insurers to gain significant market share would seem to support this analysis.

Economics has so far made very little effort to obtain a deeper understanding of markets where personal contacts with sales agents play an important role. It is thus difficult to come up with any conclusive welfare results about such situations.

I would argue that the presence of a state monopoly substantially reduces the degree of uncertainty for consumers. State monopolies have no profit motive, so they have less financial incentives to avoid reimbursing customers even in the case of important claims (as long as they are solvent). They prefer to maintain their good reputation with the population, thus reducing potential problems with their supervisory bodies. To further underline this analysis, note that in certain parts of Canada (British Columbia, Quebec) the state governments have created local monopolies in third party liability car insurance, as a result of the private insurers "reluctance" to reimburse the victims of grave personal injuries. 


\section{Risk selection}

Risk selection presents itself in a variety of different forms on this market: For most types of natural damage (flooding, subsidence) the probabilities of occurrence are very unevenly distributed within any given country. (Flooding occurs essential close to certain river beds; subsidence is limited to regions with clay soils, etc). Furthermore the very concept of "probability of occurrence" is not clearly defined. Both the occurrence of floods and the occurrence of subsidy seem have increased significantly over the last 30 years.

In a competitive environment an insurance company offering a flat premium rate across the whole country could certainly be subject to substantial problems of adverse selection. A first way to reduce the scope of adverse selection is to substantially increase excesses. (An increase in the excess increases the expected cost of damage for the customer more in those areas where the probability of damage is higher). The increase in the excess is usually accompanied by a more differentiated premium structure. The presence of these differentiated premiums is of course a strong incentive for customers to acquire more detailed information about their own risk situation. The better customers are informed about their own risk situation, the greater is the scope for adverse selection. The evolution of subsidy insurance in Britain strongly suggests that there is a dynamic development, whereby problems of adverse selection can set in motion a process in which substantial resources are invested by both customers and insurers, to come up with ever finer risk classifications and thus reduce the scope of cross subsidisation. While these developments are certainly individually rational, they are of doubtful social value.

In most of the unregulated markets we have studied only a small fraction of customers is actually covered against elementary risks (such as floods). There are a number of potential explanations for this observation.

The first explanation is once again based on adverse selection. The risk classifications the insurance companies obtain from scientific studies are usually not particularly precise. In Germany, for example, one distinguishes between three classes of flood risk. Class 1 with a probability of less than $1 \%$, class 2 with a probability between $1 \%$ and $10 \%$, and class 3 with a probability greater than $10 \%$. In class 2 the expected cost of risk can thus vary by a factor of 
1 to 10 . The potential for adverse selection thus remains substantial, assuming of course that the house owner has a finer estimation of his own risk than the insurance company.

This could be the case for several reasons. First, the house owner has more detailed information abut the exact location of his house within a given region (30 centimetres more above the water level can make a huge difference when a flood occurs). More important, the house owner usually has more detailed information about the construction of his house (are there windows opening into the cellar, are there steps leading up to the entrance, is there an expensive central heating system in the cellar etc.) There are, of course, no fundamental reasons preventing an insurance company from acquiring such information for every property in its portfolio. In view of the annual premium income involved, such a strategy is, however, prohibitively expensive (except for buildings in the highest risk category).

Note that for problems of adverse selection to play am important role it is not essential that the customers really do have such an informational advantage. Adverse selection models (such as the "lemons" model) typically have multiple equilibria. If the insurance companies are afraid of adverse selection, they will set a premium level based on the assumption that most of their customers belong to the upper end of their risk class, and this may be sufficient to dissuade most of the house owners from buying cover.

In Baden-Württemberg, where all house owners were insured against natural damages during the monopoly, most house owners have kept this cover. In Bavaria, where the former monopoly tried to introduce insurance against natural damages after the market was opened considerably less than $10 \%$ of the population have taken up this offer. We would argue that the high premium level was at least partially responsible for this lack of response. The fact that the Bavarian insurer did not submit any offer to the house owners in the highest risk class is a strong indication that adverse selection is in practice an important problem.

An alternative explanation why customers do not buy cover could be that they tend to ignore very low risks. While there is good evidence that people do actually behave in this fashion, this explanation is convincing only for the owners in the best risk classes. It is less compelling for the higher risk classes. 
In the French system of disaster insurance the problems of adverse selection are more clearcut. The private insurance companies may not be able to identify all of the good risks with precision but they can easily determine which parts of the country are very unlikely to ever be subject to the risk of floods or subsidence. It is thus easy to constitute a portfolio of customers with an above average risk profile. The need to purchase reinsurance is then low. The demand for reinsurance will come mainly from the smaller local insurance companies where the bad risks are concentrated. Under these circumstances it is quite difficult to avoid a situation, where the state pays most of the claims and the private insurance companies collect most of the premiums. Most of the adjustments to the system since its inception can be interpreted as attempts to partially resolve the inherent problems of adverse selection.

\section{Short term contracts}

Most insurance contracts are of short duration (usually one year). Even though buildings are a capital good with life span of several decades, insurance conditions can thus typically be adjusted on a short term basis. One of the main reasons for this state of affairs is probably systemic risk. The insurance companies know that the aggregate risk situation may change as a result of climate changes, increases in the number of floods, terrorist attacks etc. They do not wish to be saddled with this systemic risk. This tendency is reinforced by the fact that their own reinsurance conditions are typically also renegotiated at short intervals. The potential for long term contracts may be further limited by the fact that it is not always easy to enforce such a contract. If a customer is dissatisfied with the way a claim has been handled, can one really force him to stay with the same insurance provider for several more years?

One of the consequences of the short term nature of insurance contracts is that the conditions of insurance can be adjusted not just to new information about systemic risk, but also to information about individual risk. Subsidence in Britain is a perfect illustration for this phenomenon. The brunt of the premium increases resulting from the rise in subsidence claims is born not by the population as a whole but by the house owners in the affected regions. This uncertainty about future premiums and excesses (or sometimes even the availability of insurance cover) means that the property owner has to bear a substantial part of the risk himself. 
State monopolies in property insurance are usually based on the principal of solidarity. They do not differentiate their premiums among customer groups as new information becomes available. In a very real sense they thus offer a more complete insurance cover.

\section{The Coase Theorem}

The Coase Theorem tells us that one way to produce the optimal level of an externality is to define property rights appropriately. Britain has recently experienced an instructive illustration of this principle. If one considers the security of a railway network as being a public good, than clearly the vertical separation between Railtrack and the Train Operators does not seem to have provided the appropriate incentives as regards network security!

In property insurance one can observe a similar mechanism at work. The main beneficiaries of better prevention are the insurance companies whose claims payments fall. They thus have a strong incentive to see to it that prevention is well organised, and that the necessary resources are invested. Local authorities do not have the same clear financial incentives to invest into prevention. They pay the cost and somebody else reaps the benefits. There is a real danger that they under invest in prevention. Since prevention is typically a local public good, a local monopoly supplier on the property insurance market is in a good situation to internalise these externalities. The situation in Switzerland outlined above illustrates that these are not just theoretical considerations.

The argument presented above is not just valid for the magnitude of resources invested for fire fighting and the efficiency of these investments. It also applies to other forms of prevention. The situation in France illustrates that local authorities have only very limited incentives to declare parts of their land a flood-prone. Quite to the contrary. It may well happen that the local government can be "captured" by one of its more important land owners and make zoning decisions that cannot stand up to closer scrutiny.

The local insurance monopolies in Switzerland participate in zoning proceedings and usually have an important weight in the final decision: they can threaten not to insure the buildings and they have a strong financial incentive to do so. The participation of the insurance 
companies in zoning decisions severely limits the possibilities of local governments for taking irresponsible decisions in this area.

In the case of subsidence, appropriate building norms are of crucial importance. When the British authorities realised the importance of this problem, they adapted the construction norms. The more recent houses built on clay soils have stronger foundations and cannot be affected by subsidence. When the insurance companies participate in the development of such norms, they have a strong incentive to take into account the potential savings in terms of insurance claims. In Switzerland the building norms have been developed in close collaboration with the property insurance monopolies. They have recently been adopted even by the cantons with only private insurance providers.

One could argue that the undifferentiated premium structure of the state monopolies sets inadequate incentives for prevention. The point certainly has merits, but it seems to me to be a second order effect. The arguments set out above suggest that the most important preventive measures have the nature of (local) pubic goods. In these areas the insurance monopolies have a potentially important role to play. Compared to these factors, the possibilities of effective individual prevention are quite limited, and so are the distortionary effects of an insufficiently differentiated premium structure. One could try to argue that the state monopolies should operate with a more differentiated premium structure. But sacrificing better prevention at the local public good level, in the hope of reaping compensating benefits through improved private prevention does not seem to be a realistic proposal.

\section{Guidelines for creating a system of natural damage insurance}

If the trend of rising costs due to flooding and other natural damage continues, political pressure to provide the concerned house owners with some kind of insurance cover will increase. In designing such a system, considerations of political feasibility, efficiency and equity have to be taken into account. There is probably no unique optimal solution, since each country has its own specificities. There is however a number of considerations that should be relevant to most countries.

First, there is very little chance of introducing a monopoly system copied on the Swiss example in other countries. The private insurance industry has spent important sums to sell 
fire insurance to the house owners, and they would strongly oppose any attempt of being supplanted by a state monopoly. The only politically viable alternative is thus to look for some kind of collaboration between the state and private sector.

The French example illustrates the dangers that may arise when the state limits its actions to providing low cost reinsurance cover to the private sector. It exposes itself to substantial problems of adverse selection, providing reinsurance cover mainly for the bad risks, while the private companies keep the good risks for themselves. The most efficient way to avoid this problem is to force the private insurance sector to pass on a substantial part of the premium income from disaster insurance directly to a state monopoly. Either $100 \%$, if the state handles claims settlement itself or some lower fraction if the private sector participates in claims settlement. If the private sector's insurance agents distribute funds that come essentially from a state monopoly, problems of moral hazard are likely to become quite important. The Spanish and Swiss examples seem to indicate, that an efficient system of claims settlement does not necessarily require the participation of the private insurance sector.

An insurance system, where premiums are not continuously adjusted at an individual level as new information about risk becomes available is probably considered more equitable by the property owners. While there are no convincing reasons why premiums should not reflect risks to a certain extent, the costs of risk classification should be kept within reasonable limits.

Any system of premiums that are not actuarially fair must necessarily have some adverse incentive effects. For the specific problem of natural catastrophe insurance, most preventive measures are, however, of a local public good nature. The main issue is to provide adequate incentives in terms of zoning, construction norms and damage reduction. The presence of a local public insurance company in the relevant planning institutions should lead to a vast improvement to the current situation, since it should severely reduce problems of regulatory capture and moral hazard in this area. He has a direct financial incentive to keep damage low. An excellent way to increase the importance the public insurance provider has on the final outcome is to give him the possibility to participate financially in projects he considers important. Combining insurance premiums and a tax to finance preventive measures (including fire fighting) thus has a double advantage. It internalises the externalities usually associated with prevention, and it gives even the good risks the feeling that they are getting something for their money. 
Our country studies clearly show that there are major benefits to having a number of regional insurance monopoly, rather than one national organisation. First, regional solutions mean that yard stick competition is much easier to implement, and second smaller bodies are much more likely to implement innovative solutions to solve local problems.

We would argue that the implementation of a state monopoly solution should not encounter too much resistance from the private insurance sector. Of course, they will want to obtain some financial benefit from the introduction of such a system. But they should be willing to play along even if the amount they gain for themselves is only relatively modest. The current situation, where many of their customers do not have insurance cover against an important source of loss is not for them satisfactory. Any institutional innovation, which improves the insurance cover of their customers is thus in the joint interest of both the insurance sector and the population directly concerned.

\section{References}

von Ungern-Sternberg, T. (2003) "Property Insurance in Europe. The Limits of Competition" Oxford University Press 


\section{CESifo Working Paper Series}

(for full list see www.cesifo.de)

1002 Matthew Clarke and Sardar M. N. Islam, Health Adjusted GDP (HAGDP) Measures of the Relationship Between Economic Growth, Health Outcomes and Social Welfare, July 2003

1003 Volker Grossmann, Contest for Attention in a Quality-Ladder Model of Endogenous Growth, August 2003

1004 Marcel Gérard and Joan Martens Weiner, Cross-Border Loss Offset and Formulary Apportionment: How do they affect multijurisdictional firm investment spending and interjurisdictional tax competition?, August 2003

1005 Burkhard Heer, Nonsuperneutrality of Money in the Sidrauski Model with Heterogeous Agents, August 2003

1006 V. Anton Muscatelli, Piergiovanna Natale, and Patrizio Tirelli, A Simple and Flexible Alternative to the Stability and Growth Pact Deficit Ceilings. Is it at hand?, August 2003

1007 Reto Foellmi and Josef Zweimüller, Inequality and Economic Growth: European Versus U.S. Experiences, August 2003

1008 James S. Costain and Michael Reiter, Business Cycles, Unemployment Insurance, and the Calibration of Matching Models, August 2003

1009 Marco Runkel, Optimal Contest Design when the Designer's Payoff Depends on Competitive Balance, August 2003

1010 Donald O. Parsons, Torben Tranaes and Helene Bie Lilleør, Voluntary Public Unemployment Insurance, August 2003

1011 Rüdiger Pethig and Andreas Wagener, Profit Tax Competition and Formula Apportionment, August 2003

1012 Johan Willner, Privatisation and Public Ownership in Finland, August 2003

1013 Seppo Kari and Jouko Ylä-Liedenpohja, Taxation and Valuation of International Real Investments, August 2003

1014 James Heckman, Rosa Matzkin and Lars Nesheim, Simulation and Estimation of Hedonic Models, August 2003

1015 Biswa N. Bhattacharyay, Towards a Macro-Prudential Leading Indicators Framework for Monitoring Financial Vulnerability, August 2003 
1016 J. Stephen Ferris and Stanley L. Winer, Searching for Keynes: With Application to Canada, 1870-2000, August 2003

1017 Massimo Bordignon, Luca Colombo and Umberto Galmarini, Fiscal Federalism and Endogenous Lobbies' Formation, August 2003

1018 Annette Alstadsæter, The Dual Income Tax and Firms' Income Shifting through the Choice of Organizational Form and Real Capital Investments, August 2003

1019 Peter Fredriksson and Bertil Holmlund, Optimal Unemployment Insurance Design: Time Limits, Monitoring, or Workfare?, August 2003

1020 Kashif S. Mansori, Following in their Footsteps: Comparing Interest Parity Conditions in Central European Economies to the Euro Countries, August 2003

1021 Christoph Borgmann and Matthias Heidler, Demographics and Volatile Social Security Wealth: Political Risks of Benefit Rule Changes in Germany, August 2003

1022 Kjell Erik Lommerud, Bjørn Sandvik and Odd Rune Staume, Good Jobs, Bad Jobs and Redistribution, August 2003

1023 Patrick Karl O'Brien, The Governance of Globalization: The Political Economy of Anglo-American Hegemony, 1793-2003, September 2003

1024 Antonio Ciccone and Giovanni Peri, Skills' Substitutability and Technological Progress: U.S. States 1950-1990, September 2003

1025 Bjørn Sandvik, Optimal Taxation and Normalisations, September 2003

1026 Massimo Bordignon and Gilberto Turati, Bailing Out Expectations and Health Expenditure in Italy, September 2003

1027 José A. Herce, Namkee Ahn, Ricard Génova, and Joaquín Pereira, Bio-Demographic and Health Aspects of Ageing in the EU, September 2003

1028 John Komlos and Marieluise Baur, From the Tallest to (One of) the Fattest: The Enigmatic Fate of the American Population in the $20^{\text {th }}$ Century, September 2003

1029 Stefan Napel and Mika Widgrén, Bargaining and Distribution of Power in the EU's Conciliation Committee, September 2003

1030 Kai Li and Dale J. Poirier, Relationship Between Maternal Behavior During Pregnancy, Birth Outcome, and Early Childhood Development: An Exploratory Study, September 2003

1031 Ivar Ekeland, James J. Heckman, and Lars Nesheim, Identifcation and Estimation of Hedonic Models, September 2003

1032 Kjetil Bjorvatn and Alexander W. Cappelen, Decentralization and the Fate of Minorities, September 2003 
1033 Lars-Erik Borge and Jørn Rattsø, The Relationships Between Costs and User Charges: The Case of a Norwegian Utility Service, September 2003

1034 Maureen Were and Nancy N. Nafula, An Assessment of the Impact of HIV/AIDS on Economic Growth: The Case of Kenya, September 2003

1035 A. Lans Bovenberg, Tax Policy and Labor Market Performance, September 2003

1036 Peter Birch Sørensen, Neutral Taxation of Shareholder Income: A Norwegian Tax Reform Proposal, September 2003

1037 Roberta Dessi and Sheilagh Ogilvie, Social Capital and Collusion: The Case of Merchant Guilds, September 2003

1038 Alessandra Casarico and Carlo Devillanova, Capital-skill Complementarity and the Redistributive Effects of Social Security Reform, September 2003

1039 Assaf Razin and Efraim Sadka, Privatizing Social Security Under Balanced-Budget Constraints: A Political-Economy Approach, September 2003

1040 Michele Moretto, Paolo M. Panteghini, and Carlo Scarpa, Investment Size and Firm's Value under Profit Sharing Regulation, September 2003

1041 A. Lans Bovenberg and Peter Birch Sørensen, Improving the Equity-Efficiency Tradeoff: Mandatory Savings Accounts for Social Insurance, September 2003

1042 Bas van Aarle, Harry Garretsen, and Florence Huart, Transatlantic Monetary and Fiscal Policy Interaction, September 2003

1043 Jerome L. Stein, Stochastic Optimal Control Modeling of Debt Crises, September 2003

1044 Thomas Stratmann, Tainted Money? Contribution Limits and the Effectiveness of Campaign Spending, September 2003

1045 Marianna Grimaldi and Paul De Grauwe, Bubbling and Crashing Exchange Rates, September 2003

1046 Assar Lindbeck and Dennis J. Snower, The Firm as a Pool of Factor Complementarities, September 2003

1047 Volker Grossmann, Firm Size and Diversification: Asymmetric Multiproduct Firms under Cournot Competition, September 2003

1048 Dan Anderberg, Insiders, Outsiders, and the Underground Economy, October 2003

1049 Jose Apesteguia, Steffen Huck and Jörg Oechssler, Imitation - Theory and Experimental Evidence, October 2003

1050 G. Abío, G. Mahieu and C. Patxot, On the Optimality of PAYG Pension Systems in an Endogenous Fertility Setting, October 2003 
1051 Carlos Fonseca Marinheiro, Output Smoothing in EMU and OECD: Can We Forego Government Contribution? A Risk Sharing Approach, October 2003

1052 Olivier Bargain and Nicolas Moreau, Is the Collective Model of Labor Supply Useful for Tax Policy Analysis? A Simulation Exercise, October 2003

1053 Michael Artis, Is there a European Business Cycle?, October 2003

1054 Martin R. West and Ludger Wößmann, Which School Systems Sort Weaker Students into Smaller Classes? International Evidence, October 2003

1055 Annette Alstadsaeter, Income Tax, Consumption Value of Education, and the Choice of Educational Type, October 2003

1056 Ansgar Belke and Ralph Setzer, Exchange Rate Volatility and Employment Growth: Empirical Evidence from the CEE Economies, October 2003

1057 Carsten Hefeker, Structural Reforms and the Enlargement of Monetary Union, October 2003

1058 Henning Bohn and Charles Stuart, Voting and Nonlinear Taxes in a Stylized Representative Democracy, October 2003

1059 Philippe Choné, David le Blanc and Isabelle Robert-Bobée, Female Labor Supply and Child Care in France, October 2003

1060 V. Anton Muscatelli, Patrizio Tirelli and Carmine Trecroci, Fiscal and Monetary Policy Interactions: Empirical Evidence and Optimal Policy Using a Structural New Keynesian Model, October 2003

1061 Helmuth Cremer and Pierre Pestieau, Wealth Transfer Taxation: A Survey, October 2003

1062 Henning Bohn, Will Social Security and Medicare Remain Viable as the U.S. Population is Aging? An Update, October 2003

1063 James M. Malcomson, Health Service Gatekeepers, October 2003

1064 Jakob von Weizsäcker, The Hayek Pension: An efficient minimum pension to complement the welfare state, October 2003

1065 Joerg Baten, Creating Firms for a New Century: Determinants of Firm Creation around 1900, October 2003

1066 Christian Keuschnigg, Public Policy and Venture Capital Backed Innovation, October 2003

1067 Thomas von Ungern-Sternberg, State Intervention on the Market for Natural Damage Insurance in Europe, October 2003 